\title{
The Implications of South African Economic Growth for the Rest of Africa
}

Vivek Arora and Athanasios Vamvakidis 


\title{
IMF Working Paper
}

African and European Departments

\section{The Implications of South African Economic Growth for the Rest of Africa}

\author{
Prepared by Vivek Arora and Athanasios Vamvakidis ${ }^{1}$ \\ Authorized for distribution by Brian Ames
}

March 2005

\begin{abstract}
This Working Paper should not be reported as representing the views of the IMF. The views expressed in this Working Paper are those of the author(s) and do not necessarily represent those of the IMF or IMF policy. Working Papers describe research in progress by the author(s) and are published to elicit comments and to further debate.

This paper measures the extent to which South African economic growth is an engine of growth in sub-Saharan Africa. Results based on panel data estimation for 47 African countries over four decades suggest that South African growth has a substantial positive impact on growth in the rest of Africa, even after controlling for other growth determinants. The estimates are robust to the effects of global and regional shocks, changes in model specification, and sample period.

JEL Classification Numbers: F02, F43, O55
\end{abstract}

Keywords: Economic growth, economic integration, Africa

Author(s) E-Mail Address: varora@imf.org, avamvakidis@imf.org

\footnotetext{
${ }^{1}$ This paper was presented at the South African Bureau for Economic Research (BER) annual conference in Johannesburg, June 2004. The authors are grateful to Saúl Lizondo, Ben Smit, and BER conference participants for helpful comments. They thank Ashwini Jayaratnam for research assistance and Linda van der Westhuyzen for editorial assistance.
} 
I. Introduction 3

II. South Africa as a Trade Partner in Africa ..................................................................

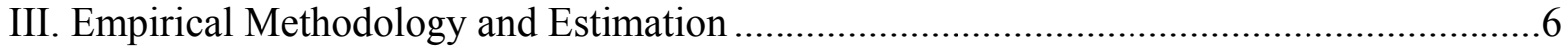

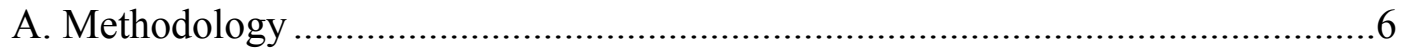

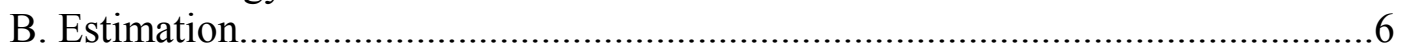

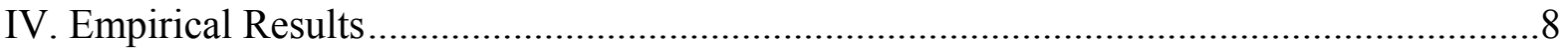

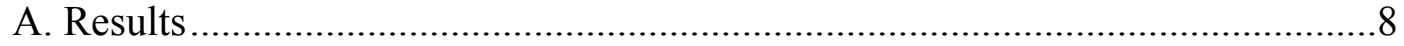

B. Discussion and Robustness Tests ............................................................... 9

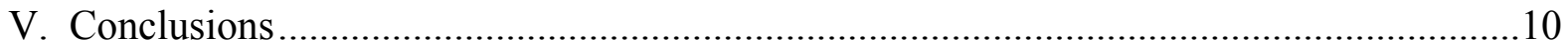

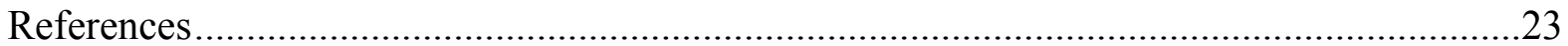

Tables

1. South Africa in the African Economy, 1970-2003 …..............................................11

2. Selected Countries: Investment from South Africa, Stocks, 1998-2002 .......................12

3. Selected Countries: Merchandise Trade with South Africa as a Percentage of

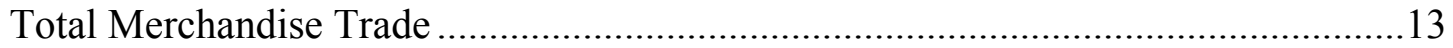

4. Selected Countries: Contribution to Real GDP Growth of Total Net Exports,

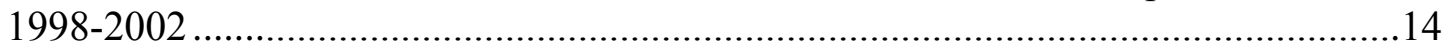

5. Contribution to Real GDP Growth of Net Exports to South Africa .............................15

6. Impact of Growth in South Africa on Growth in Rest of Sub-Saharan Africa:

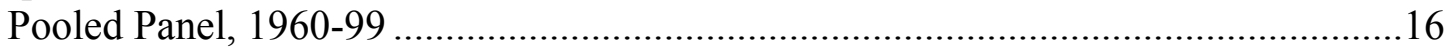

7. Impact of Growth in South Africa on Growth in Rest of Sub-Saharan Africa: Pooled Panel, 1980-99....

8. Impact of Growth in South Africa on Growth in Rest of Sub-Saharan Africa: Panel with Fixed Effects, 1960-99.....................................................................18

9. Impact of Growth in South Africa on Growth in Rest of Sub-Saharan Africa: Panel with Fixed Effects, 1980-99.

10. Impact of Growth in South Africa on Growth in Rest of Sub-Saharan Africa: The Importance of Trade Shares with and Distance from South Africa, 1960-99

11. Growth Spillovers in Sub-Saharan Africa: Impact of Each Country Other

Than South Africa: Panel with Fixed Effects, 1960-99.

12. Impact of Growth in South Africa on Growth in Rest of Sub-Saharan Africa:

Role of Regional Trends, 1960-99.... 


\section{INTRODUCTION}

South Africa is often described as an engine of growth in Africa, in the sense that South African economic growth is believed to have a substantial impact on growth in other African countries. ${ }^{2}$ This view appears plausible because of South Africa's relatively large economic size and its growing linkages with other African economies. However, there has been little quantitative assessment of just how large the effect might be. Is it relatively large, because of South Africa's economic size; or is it small, because of South Africa's economic and political isolation during the pre-1994 apartheid period and because it does not dominate the trade of most African countries, which trade mainly with Europe and the United States? This paper attempts such an assessment by providing estimates of the impact of South African economic growth on growth in the rest of Africa during the last four decades.

South African growth could influence growth in other countries through a number of channels. The most obvious channel is international trade, with higher South African growth contributing to a rise in import demand that is directly reflected in an increase in the net exports of other countries. But there are other channels as well. Given the relatively advanced state of South African technology, additional spillover effects could include an impact on investment and technology transfers along the lines discussed in the literature on trade and growth. ${ }^{3}$ Also, with South African foreign direct and portfolio investment playing a large role in the capital flows of some African countries, the effects of South African growth could be transmitted through financial linkages. Moreover, because of South Africa's size and leadership role in multi-country political and economic initiatives, ${ }^{4}$ developments there could influence business and consumer confidence in other African countries.

A quantification of the overall impact of South African growth on growth in the rest of Africa requires a formal econometric analysis. This paper reports results from such an analysis using data for 1960-99 in the context of a standard growth model. ${ }^{5}$ The analysis is based on countries' average growth rates during five-year subperiods to avoid the impact of shorter-run macroeconomic fluctuations that may be associated with transitory shocks and business cycles. The analysis does not attempt to isolate each of the channels by which South African economic growth could influence growth in other African countries, but focuses instead on quantifying the aggregate impact. Future research could assess the importance of alternative channels through which the growth spillovers might be transmitted.

\footnotetext{
${ }^{2}$ References to Africa throughout the paper relate to sub-Saharan Africa.

${ }^{3}$ See Grossman and Helpman (1991), Rivera-Batiz and Romer (1991), and Romer (1990).

${ }^{4}$ These include trade agreements such as the Southern African Customs Union (SACU) and political initiatives such as the New Partnership for African Development (NEPAD).

${ }^{5}$ Arora and Vamvakidis (2004a) discuss a similar analysis of the impact of U.S. economic growth on the rest of the world.
} 
The impact is estimated first in a simple growth regression and then in a regression that controls for other, generally accepted determinants of long-run growth. The results indicate that South African growth has a significant positive impact on growth in other African countries, with a 1-percentage-point increase in South African growth being associated with a $1 / 2-3 / 4$ percentage point increase in the rest of Africa's growth. The results hold even after controlling for global factors and are robust to the inclusion of other growth determinants and to changes in the sample and the period considered.

\section{South Africa as a Trade Partner in Africa}

The relatively large economic size of South Africa and its growing linkages with other African economies suggest that South African economic growth could have a significant influence on the rest of Africa. In 2003, South African GDP was equivalent to nearly onethird of African GDP on a purchasing power parity basis and to 38 percent of African nominal GDP at market exchange rates (Table 1). ${ }^{6}$ South Africa accounted for 30 percent of the expansion in African GDP (PPP basis) during 1980-2003, and African and South African growth moved closely together, with a correlation coefficient of over 80 percent. In terms of financial linkages, South African direct and portfolio investment in other African countries during 1998-2002 was equivalent to 5 percent of GDP on average in those countries (Table 2). ${ }^{7}$ The share was substantially larger in neighboring countries, ranging from 9 percent to 20 percent of GDP in Lesotho, Mauritius, Mozambique, Namibia, and Swaziland.

Notwithstanding its relatively large economic size, the extent of South Africa's trade with the rest of the continent has been relatively small, in part reflecting trade patterns that prevailed under the apartheid regime that ruled South Africa until 1994. Although South Africa's relative importance in regional trade has grown since 1994, it remains small compared with, for example, the regional trade shares of the United States in other Western Hemisphere countries and of China and Japan in the rest of Asia. ${ }^{8}$ During 1994-2002, the average share of South Africa in the rest of Africa's external trade rose to three times its 1970-93 average, but it was still only 2 percent of the total. As a percent of GDP, the rest of Africa's trade with South Africa during 1994-2002 rose to four times its 1970-93 average level, but it was equivalent to only $1 \frac{1}{2}$ percent of GDP.

\footnotetext{
${ }^{6}$ Authors' calculations, based on IMF World Economic Outlook data.

${ }^{7}$ The weighted average was equivalent to $1 \frac{1}{2}$ percent of African GDP. It was smaller than the simple average because South Africa's economic links have generally been stronger with some of the smaller African countries (such as its neighbors) than with the larger ones (such as Nigeria).

${ }^{8}$ In 2002, the United States accounted for 60 percent of the total external trade of other North American and South American countries. China and Japan accounted for over 10 percent and 15 percent, respectively, of other Asian countries' external trade.
} 
The relative importance of South Africa in the trade of individual African countries varies substantially across the continent (Table 3). Trade with South Africa accounts for around three-quarters of the total trade of neighboring Lesotho and Swaziland, with which South Africa participates (along with Botswana and Namibia) in the Southern African Customs Union (SACU). ${ }^{9}$ During 1998-2002, trade with South Africa accounted on average for 26-56 percent of the foreign trade of other neighboring countries, namely Botswana, Malawi, Mozambique, Namibia, Zambia, and Zimbabwe. And it accounted for over 5 percent of foreign trade in Comoros, the Democratic Republic of Congo, Kenya, Mauritius, Seychelles, and Tanzania. In Nigeria, Africa's second largest economy, trade with South Africa was equivalent to $1 \frac{1}{4}$ percent of total trade. In countries that are geographically distant from South Africa or that are former French colonies, trade with South Africa has generally accounted for less than 1 percent of foreign trade. ${ }^{10}$

A simple measure that captures the direct effect of trade on a country's growth is the contribution to growth of its net exports. Specifically, the growth contribution can be calculated as the change in real net exports in the current year as a percent of real GDP in the previous year (Table 4). ${ }^{11}$ By extension, the direct effect of trade with South Africa on a country's growth can be calculated as the growth contribution of the country's real net exports to South Africa (Table 5). ${ }^{12}$ On this basis, while overall net exports made on average a negative contribution of -0.4 percentage points in the selected countries during 1999-2002, net exports to South Africa made a small positive contribution ( 0.1 percentage points). The growth contribution was significantly larger in countries with close trading links with South Africa (e.g., Comoros, Mozambique, Zimbabwe). In several countries, where South Africa is more important as a source of imports than as a destination for exports, net imports from South Africa were reflected in a negative net contribution to growth.

However, the direct impact of net exports to South Africa represents only part of the overall impact of South African growth on growth in other countries. In particular, even if they run bilateral deficits, countries may benefit from trade with South Africa as a result of factors such as greater efficiency, economies of scale, and technological gains associated with such

\footnotetext{
${ }^{9}$ This is based on historical data cited in the countries' official statistics and in the UN Comtrade database, since the countries do not report bilateral trade data to the IMF Direction of Trade Statistics, on which the rest of Table 3 is based.

${ }^{10}$ Such countries include Burkina Faso, Cameroon, Cape Verde, Central African Republic, Chad, Côte d'Ivoire, Ethiopia, Gabon, Guinea, Guinea-Bissau, Mauritania, Niger, Senegal, and Togo.

${ }^{11}$ The bilateral trade data in the Direction of Trade Statistics are available only starting in 1998.

12 That is, the contribution of a country's real net exports (NX) to its real GDP (Y) growth in a year, $\mathrm{t}$, can be calculated as $\Delta \mathrm{NX}_{\mathrm{t}} / \mathrm{Y}_{\mathrm{t}-1}$, and the contribution of its net exports to South Africa $\left(\mathrm{NX}^{\mathrm{SA}}\right)$ can be calculated as $\Delta \mathrm{NX}_{\mathrm{t}}^{\mathrm{SA}} / \mathrm{Y}_{\mathrm{t}-1}$.
} 
trade. Also, the effects of South African economic growth are likely to extend beyond just the trade effect, including through such channels as economic sentiment and financial linkages. A more complete analysis of the impact of South African growth thus requires a formal econometric analysis.

\section{EMPIRICAL METHODOLOGY AND ESTIMATION}

\section{A. Methodology}

The impact of South African growth on growth in the rest of Africa can be quantified by estimating a panel regression both with and without fixed effects. ${ }^{13}$ The panel approach allows one to control for other explanatory variables in the growth regression and to test the robustness of the results to changes in model specification. Furthermore, the fixed-effects estimator allows the constant term to differ across cross-section units and it captures the time series dimension of the effect of South African growth after controlling for other growth determinants.

\section{B. Estimation}

The empirical framework follows Arora and Vamvakidis (2004a). It starts with a growth regression specification that is standard in the literature: ${ }^{14}$

$(\text { Real GDP per capita growth })_{i}=\boldsymbol{c}_{\boldsymbol{i}}+\boldsymbol{\beta} \boldsymbol{X}_{\boldsymbol{i}}+\boldsymbol{u}, \quad$ for country $i=1, \ldots, n$

The dependent variable is the average per capita real GDP growth rate; $\mathbf{c}_{\mathbf{i}}$ is the matrix of constant terms for each country $i ; \boldsymbol{\beta}$ is the matrix of parameters to be estimated and $\mathbf{u}$ is the error term. $\mathbf{X}_{\mathbf{i}}$ is the matrix of independent variables that includes the variables that are standard in growth regressions:

- $\quad$ convergence (the logarithm of per capita real GDP in the initial year of the period under consideration); ${ }^{15}$

- $\quad$ demographic developments (age dependency ratio);

- $\quad$ investment in physical capital (gross domestic investment as a percent of GDP);

${ }^{13}$ A simple cross-country estimation would not be valid since growth in South Africa enters for all countries in the sample.

${ }^{14}$ See, for example, Barro and Sala-ì-Martin (1995).

${ }^{15}$ Caselli, Esquivel, and Lefort (1996) have argued that initial GDP per capita is endogenous. However, excluding it from the regressions in the present analysis did not change the conclusions. 
- $\quad$ human capital (primary and secondary school enrollment ratios);

- $\quad$ macroeconomic stability (inflation); and

- $\quad$ trade openness (the share of external trade in GDP). ${ }^{16}$

To account for variables that have been found to be statistically significant in explaining growth in Africa, $\mathbf{X}_{\mathbf{i}}$ includes: ${ }^{17}$

- $\quad$ foreign aid as a percent of GDP;

- $\quad$ the infant mortality rate;

- $\quad$ a dummy variable for landlocked countries;

- ethnic fractionalization.

In addition, to estimate the impact of growth in South Africa on the rest of Africa, $\mathbf{X}_{\mathbf{i}}$ includes:

- the growth rate of real per capita GDP in South Africa;

- $\quad$ the growth rate of real per capita GDP in each of the other African countries (one in each specification) to test whether any of the other countries also act as an engine of growth for Africa.

Finally, in order to test whether the results are driven by global or regional trends, $\mathbf{X}_{\mathbf{i}}$ includes:

- world real per capita GDP growth;

- growth of real per capita GDP in trading partners;

- regional growth.

All data are from the Global Development Network Growth Database. ${ }^{18}$ The growth model is estimated for two periods, 1960 to 1999 and 1980 to 1999. All 47 countries in sub-Saharan

\footnotetext{
${ }^{16}$ The trade share is one of the most broadly used measures of openness in the literature and among the most robust (see Levine and Renelt, 1992). One of its main advantages is that it varies over time.

${ }^{17}$ See for example Bloom and Sachs (1998).

${ }^{18} \mathrm{http}: / /$ www.worldbank.org/research/growth/GDNdata.htm
} 
Africa with available data are included in the sample. South Africa is excluded from the sample as its growth rate is one of the independent variables. Each observation is a five-year average except for the initial GDP per capita, which takes the value of the first year of each five-year period, and the variables that do not change over time (these variables are not included in the regression when fixed effects are included). The use of a fixed rather than a random-effects model is justified by a Hausman test, which rejects the hypothesis that the individual effects are uncorrelated with the other regressors for most specifications.

\section{EMPIRICAL RESULTS}

A simple specification is initially estimated with per capita GDP growth in each African country as the dependent variable and per capita GDP growth in South Africa as the independent variable. Then, in order to test the robustness of the results, the model is estimated first with other independent variables, and then with only those variables that turn out to be statistically significant. Finally, a number of different specifications are tried as additional tests of robustness.

A notable difference between the present analysis and several previous analyses is that it examines variations in growth across African countries, rather than between Africa and the rest of the world. One implication of this is that, although all of the determinants included in the regressions have been found to be statistically significant in studies of growth across countries worldwide, some of the variables turn out not to be statistically significant in the present analysis. That is, some variables that are significant in explaining differences in growth between Africa and other parts of the world may not help to explain growth differences within Africa. For example, a factor that has been emphasized in accounting for Africa's weak growth relative to other regions is the relatively high trade barriers in most African countries. ${ }^{19}$ However, if most African economies are relatively closed, then while this might help to explain Africa's growth relative to other regions, it should not be expected to explain much of the growth variation within Africa. This indeed turns out to be the case.

\section{A. Results}

Results for the pooled panel for the period 1960-1999 are presented in Table 6. The first four regressions present results from specifications that add different growth determinants. ${ }^{20}$ The first regression includes only the growth rate in South Africa; the second adds the initial GDP per capita and the investment share; the third adds other variables that have been found to explain cross-country growth differences in the literature; and the fourth regression adds variables that are more specific to Africa and have been found to explain growth differences between African and non-African countries, as well as variables that control for world growth trends. Finally, the fifth regression includes only the statistically significant variables. The results suggest that growth in South Africa is a statistically significant determinant of

${ }^{19}$ See Sachs and Warner (1995).

${ }^{20}$ This is also how subsequent results are presented. 
growth in the rest of Africa, after controlling for other growth determinants. The estimates suggest that a rise in growth in South Africa by 1 percentage point is correlated with a rise in growth in the rest of Africa by 0.4 to 0.7 percentage points.

The same exercise is repeated in Table 7 for the period 1980-99. The results still hold. In fact, the estimate of the growth impact of South Africa is actually larger for this period than for 1960-99 in some specifications. A 1 percentage point increase in South African growth is correlated with a 0.4-0.9 percentage point increase in growth in the rest of Africa, depending on the specification. Table 8 presents estimates with fixed effects for the period 1960-99. Since the fixed effects capture the cross-country variations in growth, the estimates capture only the time variation. The results suggest, once again, that higher growth in South Africa is correlated with higher growth in the rest of Africa. More specifically, a 1 percentage point rise in growth in South Africa is correlated with a 0.5-0.7 percentage point rise in growth in the rest of Africa.

Table 9 presents estimates with fixed effects for the period 1980-99. In this case, the estimates for the growth impact of South Africa on the rest of Africa are somewhat smaller than the estimates in Table 8. ${ }^{21}$ A 1 percentage point increase in growth in South Africa is correlated with a 0.3-0.6 percentage point increase in growth in the rest of Africa.

\section{B. Discussion and Robustness Tests}

The results suggest that growth in South Africa and in the rest of sub-Saharan Africa are closely correlated. The results are robust to the inclusion of fixed effects and of time effects. They are also robust to changes in the sample period and to changes in the specification to include GDP growth, rather than per capita GDP growth, in South Africa. ${ }^{22}$ The results are not driven by global trends or shocks. All tables present specifications that control for world growth and for growth in trading partner countries. The estimate of the impact of growth in South Africa on the rest of Africa remains statistically significant in these specifications.

The results do not differ for the period after 1994. An increase in economic integration between South Africa and the rest of Africa after the end of apartheid might have been expected to result in greater spillover effects. However, an interaction term of growth in South Africa with a dummy variable for the second half of the 1990s does not turn out to be statistically significant. This is consistent with the fact, noted above, that although South Africa's relative importance in regional trade has grown since 1994, it remains small.

${ }^{21}$ In addition, some of the other growth determinants that are statistically significant in the full specification turn out not to be significant in the parsimonious specification.

22 The results of this and other robustness tests are available from the authors on request. All of the results are robust when the standard errors are adjusted according to the methodology suggested by Moulton (1990) for units with common characteristics. See Arora and Vamvakidis (2004b) for a discussion. 
The results do not seem to depend on the size of countries' bilateral trade with South Africa, or their distance from South Africa. Table 10 presents results from a regression that includes: an interaction term of growth in South Africa with the share of exports to South Africa in total exports; and growth in South Africa weighted by distance from South Africa. Specifications with and without fixed effects show that these variables are not statistically significant when growth in South Africa is also included in the regression, suggesting that the impact of the South African economy on the rest of Africa does not depend on trade or distance. These results are not surprising given the relatively small trade flows between other African countries and South Africa. They suggest that channels not directly related to trade, discussed above, could explain the growth spillovers from South Africa to the rest of Africa.

Moreover, South Africa is the only country in sub-Saharan Africa with such a growth impact. Table 11 presents results of the specification with fixed effects, for the period 1960-99, for the fourth regression in Table 8, testing the growth impact of all other countries in the region - only for countries with at least 6 observations. Only seven countries have a statistically significant impact, three of which are significant only at the 10 percent level. However, none of these estimates is robust to the alternative specifications presented above for South Africa, or to the inclusion of time effects. Furthermore, the estimates of the growth impact are generally considerably smaller than those for South Africa.

Granger causality tests of growth in each country in Africa with growth in South Africa are inconclusive. However, such tests use annual data, as opposed to five-year averages in the above specifications, implying that they capture short-term growth fluctuations rather than long-term growth spillovers. The period is too short for Granger causality tests using fiveyear averages. Furthermore, Granger causality tests do not control for other growth determinants, as in the regressions above.

The results are not driven by regional trends. Table 12 presents results from a regression that includes the average per capita GDP growth in the rest of Africa-excluding South Africa and the country of each observation. The estimate for the impact of the growth of South Africa remains positive and statistically significant. Moreover, it is considerably larger than the estimate of growth in the rest of Africa, which is only statistically significant at the 10 percent level.

\section{Conclusions}

The significant estimated impact of South African growth on the rest of Africa lends substance to the popular view of South Africa as an engine of African growth. Based on data for the period 1960-99, the panel regression results indicate that a 1 percentage point increase in South African economic growth is correlated with a $1 / 2-3 / 4$ percentage point increase in growth in the rest of Africa. The coefficient remains significant when non-South-African growth is included in the regression, and it is larger than that of non-South-African growth, suggesting that the influence of South African growth is distinct from any common regional shocks that may affect growth across different African countries and also that it dominates the effect of any such shocks. Since trade does not seem to explain these results, future research can focus on examining the significance of alternative channels. 
Table 1. South Africa in the African Economy, 1970-2003 (in percent)

\begin{tabular}{|c|c|c|c|c|}
\hline & 1970 & 1980 & 1990 & 2003 \\
\hline \multicolumn{5}{|c|}{$\begin{array}{l}\text { Proportion of sub-Saharan Africa's GDP accounted } \\
\text { for by South Africa: }\end{array}$} \\
\hline At market exchange rates & 34.2 & 28.6 & 35.7 & 37.8 \\
\hline At purchasing-power parity & 33.8 & 35.2 & 33.6 & 31.8 \\
\hline \multicolumn{5}{|c|}{$\begin{array}{l}\text { Share of merchandise trade with South Africa } \\
\text { in other African countries': }\end{array}$} \\
\hline Total merchandise trade & 0.8 & 0.4 & 0.7 & 2.3 \\
\hline GDP & 0.4 & 0.2 & 0.4 & 1.6 \\
\hline
\end{tabular}

Sources: IMF Direction of Trade Statistics and World Economic Outlook. 1/ Data are for 2002, and include both sub-Saharan and North Africa. 
Table 2. Selected Countries: Investment from South Africa, Stocks, 1998-2002 (in percent of GDP)

\begin{tabular}{lrrrrr}
\hline & 1998 & 1999 & 2000 & 2001 & 2002 \\
\hline Angola & 0.1 & 0.1 & 0.1 & 0.3 & 0.1 \\
Botswana & 7.0 & 3.3 & 3.1 & 3.3 & 2.4 \\
Comoros & 2.6 & 2.3 & 2.7 & 0.2 & 0.1 \\
Congo, Dem. Rep. of & 0.8 & 0.4 & 0.3 & 4.1 & 0.2 \\
Ghana & 0.1 & 0.0 & 0.1 & 0.8 & 0.4 \\
& & & & & \\
Kenya & 0.1 & 0.1 & 0.1 & 0.3 & 0.2 \\
Lesotho & 10.6 & 21.3 & 29.4 & 29.5 & 11.7 \\
Madagascar & 0.6 & 0.1 & 0.0 & 0.0 & 0.0 \\
Malawi & 3.0 & 2.3 & 2.5 & 1.3 & 3.7 \\
Mauritius & 5.8 & 22.2 & 22.8 & 19.1 & 15.6 \\
& & & & & \\
Mozambique & 1.8 & 12.1 & 16.4 & 16.7 & 22.0 \\
Namibia & 10.1 & 8.7 & 9.2 & 7.5 & 10.1 \\
Nigeria & 0.0 & 0.0 & 0.0 & 0.0 & 0.0 \\
Seychelles & 0.4 & 0.0 & 1.3 & 3.0 & 2.0 \\
Swaziland & 23.0 & 21.5 & 20.1 & 6.5 & 5.3 \\
& & & & & \\
Tanzania & 0.5 & 0.2 & 0.3 & 0.7 & 0.7 \\
Uganda & 0.0 & 0.3 & 0.3 & 0.8 & 1.8 \\
Zambia & 2.4 & 1.7 & 1.8 & 4.5 & 4.3 \\
Zimbabwe & 3.3 & 3.8 & 2.1 & 1.6 & 0.6 \\
Simple average & & & & & \\
Total, Africa & 3.8 & 5.3 & 5.9 & 5.3 & 4.3 \\
& 1.5 & 1.8 & 1.7 & 1.5 & 1.2 \\
\hline
\end{tabular}

Sources: South African Reserve Bank (for data in South African rand); IMF World Economic Outlook database (for exchange rate and GDP); and authors' calculations (conversion of rand data to shares in GDP). 
Table 3. Selected Countries: Merchandise Trade with South Africa as a Percentage of Total Merchandise

\begin{tabular}{|c|c|c|c|c|c|c|}
\hline \multicolumn{7}{|c|}{ Trade } \\
\hline & 1998 & 1999 & 2000 & 2001 & 2002 & Avg. 1998-2002 \\
\hline Angola & 3.5 & 2.7 & 3.2 & 4.3 & 3.8 & 3.5 \\
\hline Benin & 2.3 & 2.0 & 2.6 & 2.5 & 2.7 & 2.5 \\
\hline Burkina Faso & 0.2 & 0.2 & 0.6 & 0.9 & 0.9 & 0.7 \\
\hline Burundi & 2.1 & 2.7 & 4.0 & 1.9 & 2.3 & 2.7 \\
\hline Cameroon & 0.5 & 0.4 & 0.7 & 0.8 & 0.8 & 0.7 \\
\hline Cape Verde & 1.1 & 1.3 & 0.4 & 0.7 & 0.6 & 0.8 \\
\hline Central African Republic & 0.3 & 0.3 & 0.2 & 0.2 & 0.2 & 0.2 \\
\hline Chad & 0.0 & 0.0 & 0.1 & 0.0 & 0.0 & 0.0 \\
\hline Comoros & 37.3 & 25.5 & 17.4 & 14.7 & 12.6 & 17.5 \\
\hline Congo, Dem. Rep. of & 10.2 & 9.3 & 8.2 & 7.6 & 6.4 & 7.9 \\
\hline Congo, Rep. of & 1.0 & 1.1 & 1.0 & 1.1 & 1.1 & 1.0 \\
\hline Côte d'Ivoire & 0.8 & 0.8 & 0.8 & 0.8 & 0.7 & 0.8 \\
\hline Djibouti & 0.1 & 1.1 & 1.1 & 1.5 & 1.5 & 1.3 \\
\hline Ethiopia & 1.0 & 0.8 & 0.6 & 0.6 & 0.6 & 0.6 \\
\hline Gabon & 0.6 & 0.6 & 0.6 & 0.7 & 0.7 & 0.6 \\
\hline Gambia, The & 0.4 & 1.1 & 1.2 & 1.5 & 1.5 & 1.3 \\
\hline Ghana & 1.8 & 1.9 & 2.2 & 2.3 & 2.5 & 2.2 \\
\hline Guinea & 0.8 & 0.9 & 0.5 & 0.6 & 0.6 & 0.7 \\
\hline Guinea-Bissau & 0.2 & 0.1 & 0.2 & 0.2 & 0.2 & 0.2 \\
\hline Kenya & 4.8 & 4.8 & 4.7 & 5.1 & 5.3 & 5.0 \\
\hline Lesotho & n.a. & n.a. & 61.0 & 82.7 & 66.4 & 70.0 \\
\hline Madagascar & 4.5 & 3.2 & 2.6 & 1.3 & 0.2 & 1.8 \\
\hline Malawi & 29.0 & 30.3 & 36.6 & 35.1 & 33.9 & 34.0 \\
\hline Mali & 1.8 & 1.8 & 3.6 & 2.1 & 2.1 & 2.4 \\
\hline Mauritania & 0.3 & 0.2 & 0.3 & 0.5 & 0.5 & 0.4 \\
\hline Mauritius & 5.3 & 16.4 & 8.6 & 8.1 & 7.9 & 10.2 \\
\hline Morocco & 0.4 & 0.2 & 0.3 & 0.5 & 0.5 & 0.4 \\
\hline Mozambique & 48.1 & 52.5 & 51.3 & 35.2 & 24.2 & 40.8 \\
\hline Namibia & n.a. & n.a. & 57.0 & 59.8 & 51.7 & 56.2 \\
\hline Niger & 0.2 & 0.1 & 0.2 & 0.4 & 0.3 & 0.3 \\
\hline Nigeria & 0.7 & 1.2 & 1.0 & 1.3 & 1.4 & 1.2 \\
\hline Rwanda & 3.8 & 2.8 & 2.0 & 2.8 & 3.4 & 2.7 \\
\hline São Tomé and Príncipe & 6.3 & 3.8 & 2.3 & 1.0 & 1.0 & 2.0 \\
\hline Senegal & 0.4 & 0.5 & 0.6 & 1.0 & 0.8 & 0.7 \\
\hline Seychelles & 7.3 & 7.1 & 6.8 & 5.9 & 6.6 & 6.6 \\
\hline Sierra Leone & 4.5 & 3.1 & 1.8 & 2.0 & 1.6 & 2.1 \\
\hline Swaziland & n.a. & n.a. & 78.2 & 87.1 & 76.5 & 80.6 \\
\hline Tanzania & 9.6 & 9.0 & 10.5 & 8.8 & 7.9 & 9.1 \\
\hline Togo & 1.2 & 0.9 & 0.7 & 0.8 & 0.8 & 0.8 \\
\hline Uganda & 3.8 & 2.8 & 3.7 & 4.3 & 4.3 & 3.8 \\
\hline Zambia & 23.5 & 26.0 & 47.2 & 43.8 & 47.9 & 41.3 \\
\hline Zimbabwe & 28.7 & 29.0 & 24.0 & 24.4 & 27.7 & 26.3 \\
\hline
\end{tabular}

Sources: Calculations based on IMF Direction of Trade Statistic; UN Comtrade Statistics (for Lesotho Namibia, and Swaziland); and IMF World Economic Outlook. 
Table 4. Selected Countries: Contribution to Real GDP Growth of Total Net Exports, 1998-2002

\begin{tabular}{|c|c|c|c|c|c|c|}
\hline & 1998 & 1999 & 2000 & 2001 & 2002 & Avg. 1998-2002 \\
\hline Benin & 1.4 & -1.9 & -1.5 & 0.0 & -1.5 & -1.2 \\
\hline Burkina Faso & -1.6 & 0.3 & 0.3 & -0.2 & 0.9 & 0.4 \\
\hline Burundi & -18.6 & -3.2 & -6.1 & -5.9 & -8.6 & -5.9 \\
\hline Cameroon & 0.1 & 1.8 & -2.6 & -1.6 & -3.7 & -1.5 \\
\hline Cape Verde & -6.2 & -7.5 & 4.3 & -2.6 & -6.3 & -3.0 \\
\hline Central African Republic & -1.7 & 1.3 & 2.3 & -0.2 & 0.6 & 1.0 \\
\hline Chad & -2.1 & -0.8 & -0.3 & -19.3 & -16.5 & -9.2 \\
\hline Comoros & -2.2 & 1.3 & 2.7 & -1.7 & -1.5 & 0.2 \\
\hline Congo, Rep. of & 5.8 & -2.6 & -2.9 & -7.0 & -2.5 & -3.7 \\
\hline Côte d'Ivoire & -0.2 & 0.8 & 0.7 & -0.7 & 0.8 & 0.4 \\
\hline Djibouti & -7.6 & 17.1 & -1.5 & 1.9 & -2.7 & 3.7 \\
\hline Equatorial Guinea & 13.2 & -24.9 & 0.4 & -7.9 & 50.8 & 4.6 \\
\hline Eritrea & -5.7 & 0.6 & 2.4 & -8.7 & 5.4 & -0.1 \\
\hline Ethiopia & -1.8 & -2.9 & 1.6 & 0.1 & -0.7 & -0.5 \\
\hline Gabon & -7.2 & 3.1 & -5.9 & -2.8 & -2.3 & -2.0 \\
\hline Gambia, The & -4.1 & 1.8 & 0.0 & 4.1 & -2.5 & 0.9 \\
\hline Ghana & 1.5 & -2.4 & 7.4 & -2.6 & 1.7 & 1.0 \\
\hline Guinea & -0.2 & 0.4 & 0.5 & 2.8 & -3.6 & 0.0 \\
\hline Guinea-Bissau & 0.4 & 6.0 & -6.0 & -12.3 & 8.6 & -0.9 \\
\hline Kenya & -0.6 & 3.1 & -4.7 & 0.7 & 5.3 & 1.1 \\
\hline Lesotho & 16.2 & 1.0 & 6.1 & 6.0 & -4.1 & 2.2 \\
\hline Madagascar & 0.8 & -0.4 & 1.4 & 3.0 & -2.6 & 0.3 \\
\hline Malawi & 15.1 & -11.5 & 5.1 & 0.1 & -7.9 & -3.5 \\
\hline Mali & -1.0 & 2.1 & -3.6 & 1.4 & 6.5 & 1.6 \\
\hline Mauritania & -3.2 & 4.3 & -1.6 & -2.7 & -4.3 & -1.1 \\
\hline Mauritius & 0.0 & 0.8 & -2.7 & 5.0 & 0.6 & 0.9 \\
\hline Morocco & -1.4 & -0.5 & -2.9 & 0.2 & 0.2 & -0.7 \\
\hline Mozambique & -2.2 & -14.6 & 7.4 & 26.6 & -13.1 & 1.6 \\
\hline Namibia & -0.3 & 2.3 & 2.3 & -2.4 & -0.8 & 0.4 \\
\hline Niger & -1.7 & 0.8 & -0.5 & -0.6 & -2.7 & -0.7 \\
\hline Nigeria & 3.0 & -10.6 & 13.0 & -7.8 & -13.2 & -4.6 \\
\hline Rwanda & -1.0 & 1.6 & 3.3 & 1.4 & -1.1 & 1.3 \\
\hline São Tomé and Príncipe & 1.0 & -9.4 & -1.8 & -0.8 & 5.5 & -1.6 \\
\hline Senegal & -1.1 & 0.1 & -1.6 & -1.1 & -0.9 & -0.9 \\
\hline Seychelles & -7.5 & 7.5 & 13.2 & -13.8 & 12.1 & 4.8 \\
\hline Sierra Leone & -7.5 & 4.2 & -13.7 & -5.3 & -10.8 & -6.4 \\
\hline Swaziland & -0.8 & 0.8 & 2.2 & 5.7 & 0.1 & 2.2 \\
\hline Tanzania & -9.0 & -2.6 & 0.4 & 0.7 & 0.7 & -0.2 \\
\hline Togo & -3.7 & 5.2 & -1.9 & 1.0 & -0.8 & 0.9 \\
\hline Uganda & -3.7 & 0.6 & 1.0 & 0.6 & -0.7 & 0.4 \\
\hline Zimbabwe & 1.6 & 5.1 & 0.3 & -4.7 & -2.6 & -0.5 \\
\hline
\end{tabular}

Sources: Calculations based on IMF, Direction of Trade Statistics and World Economic Outlook. 
Table 5. Contribution to Real GDP Growth of Net Exports to South Africa (in percentage points) $1 /$

\begin{tabular}{|c|c|c|c|c|c|}
\hline & 1999 & 2000 & 2001 & 2002 & Avg. 1998-2002 \\
\hline Benin & -0.1 & -0.2 & 0.0 & 0.0 & -0.1 \\
\hline Burundi & 0.0 & -2.1 & 1.5 & -0.4 & -0.3 \\
\hline Cameroon & 0.0 & -0.2 & -0.1 & 0.0 & -0.1 \\
\hline Cape Verde & -0.2 & 0.5 & -0.2 & 0.0 & 0.0 \\
\hline Central African Republic & 0.0 & 0.0 & 0.0 & 0.0 & 0.0 \\
\hline Chad & 0.0 & 0.0 & 0.0 & 0.0 & 0.0 \\
\hline Comoros & 1.8 & 1.3 & 0.1 & -0.1 & 0.8 \\
\hline Congo, Rep. of & 0.1 & -0.3 & 0.2 & -0.3 & -0.1 \\
\hline Cote d'Ivoire & -0.1 & 0.0 & 0.0 & 0.0 & 0.0 \\
\hline Djibouti & -0.5 & 0.0 & -0.2 & -0.1 & -0.2 \\
\hline Ethiopia & -0.1 & 0.1 & 0.0 & 0.0 & 0.0 \\
\hline Gabon & 0.0 & -0.1 & 0.0 & 0.0 & 0.0 \\
\hline Gambia, The & 0.3 & 0.0 & 0.1 & 0.0 & 0.1 \\
\hline Ghana & -0.1 & 0.0 & -0.1 & -0.1 & -0.1 \\
\hline Guinea & -0.1 & 0.1 & 0.0 & 0.0 & 0.0 \\
\hline Guinea-Bissau & 0.0 & -0.1 & 0.0 & 0.0 & 0.0 \\
\hline Kenya & 0.1 & -0.2 & -0.2 & -0.1 & -0.1 \\
\hline Madagascar & 0.0 & -0.1 & 0.6 & 0.5 & 0.2 \\
\hline Malawi & -1.7 & 1.0 & 0.6 & -0.6 & -0.2 \\
\hline Mali & -0.4 & -0.8 & 0.5 & -0.2 & -0.2 \\
\hline Mauritania & 0.1 & -0.1 & -0.1 & 0.0 & 0.0 \\
\hline Mauritius & -2.3 & -0.2 & 0.3 & 0.5 & -0.4 \\
\hline Morocco & 0.0 & -0.1 & -0.1 & 0.0 & -0.1 \\
\hline Mozambique & -14.9 & 4.0 & 12.7 & 7.2 & 2.3 \\
\hline Niger & 0.0 & -0.1 & 0.0 & 0.0 & 0.0 \\
\hline Nigeria & 0.4 & -0.3 & 0.1 & 0.0 & 0.1 \\
\hline Rwanda & 0.3 & 0.2 & -0.1 & 0.0 & 0.1 \\
\hline São Tomé and Príncipe & 1.2 & 0.9 & 0.7 & 0.0 & 0.7 \\
\hline Senegal & -0.1 & 0.0 & -0.2 & 0.1 & -0.1 \\
\hline Seychelles & 0.4 & -0.2 & -0.4 & 0.2 & 0.0 \\
\hline Sierra Leone & 1.1 & 0.2 & -0.2 & -0.1 & 0.3 \\
\hline Tanzania & 0.1 & -0.7 & 0.3 & 0.5 & 0.0 \\
\hline Togo & -0.4 & 0.3 & -0.8 & 0.0 & -0.2 \\
\hline Uganda & 0.1 & -0.1 & -0.1 & -0.1 & 0.0 \\
\hline Zimbabwe & 1.4 & 2.5 & -1.9 & -0.5 & 0.4 \\
\hline
\end{tabular}

Sources: Calculations based on IMF, Direction of Trade Statistics and World Economic Outlook.

1/ Calculations are reported only for countries for which trade data are published in Direction of Trade Statistics. 
Table 6. Impact of Growth in South Africa on Growth in Rest of Sub-Saharan Africa: Pooled Panel, 1960-99

\begin{tabular}{|c|c|c|c|c|c|}
\hline Independent Variables & $(1)$ & $(2)$ & (3) & (4) & (5) \\
\hline Constant & $\begin{array}{c}0.47 \\
(2.16)\end{array}$ & $\begin{array}{l}-3.60 \\
(-1.40)\end{array}$ & $\begin{array}{l}-4.15 \\
(-0.73)\end{array}$ & $\begin{array}{c}5.12 \\
(0.81)\end{array}$ & $\begin{array}{c}-0.70 \\
(-0.70)\end{array}$ \\
\hline $\begin{array}{l}\text { Per capita GDP growth in } \\
\text { South Africa }\end{array}$ & $\begin{array}{c}0.42 \\
(4.13)\end{array}$ & $\begin{array}{c}0.67 \\
(5.59)\end{array}$ & $\begin{array}{c}0.71 \\
(4.92)\end{array}$ & $\begin{array}{c}0.76 \\
(3.31)\end{array}$ & $\begin{array}{c}0.72 \\
(5.76)\end{array}$ \\
\hline ln (initial GDP per capita) & & $\begin{array}{c}0.06 \\
(0.14)\end{array}$ & $\begin{array}{c}0.47 \\
(0.68)\end{array}$ & $\begin{array}{c}-0.29 \\
(-0.38)\end{array}$ & \\
\hline Investment/GDP & & $\begin{array}{c}0.20 \\
(4.91)\end{array}$ & $\begin{array}{c}0.20 \\
(4.65)\end{array}$ & $\begin{array}{c}0.32 \\
(5.91)\end{array}$ & $\begin{array}{c}0.15 \\
(5.36)\end{array}$ \\
\hline Age dependency ratio & & & $\begin{array}{c}-0.68 \\
(-0.23)\end{array}$ & $\begin{array}{l}-3.49 \\
(-1.18)\end{array}$ & \\
\hline Trade/GDP & & & $\begin{array}{c}-0.01 \\
(-0.68)\end{array}$ & $\begin{array}{c}-0.03 \\
(-2.06)\end{array}$ & \\
\hline Primary school enrollment & & & $\begin{array}{c}-0.01 \\
(-0.62)\end{array}$ & $\begin{array}{c}-0.02 \\
(-1.25)\end{array}$ & \\
\hline Secondary school enrollment & & & $\begin{array}{l}-0.00 \\
(-0.07)\end{array}$ & $\begin{array}{c}0.00 \\
(0.10)\end{array}$ & \\
\hline Inflation rate & & & $\begin{array}{l}-0.001 \\
(-8.32)\end{array}$ & $\begin{array}{l}-0.001 \\
(-8.83)\end{array}$ & $\begin{array}{l}-0.001 \\
(-8.50)\end{array}$ \\
\hline Aid/GDP & & & & $\begin{array}{c}0.04 \\
(1.28)\end{array}$ & \\
\hline Infant mortality rate & & & & $\begin{array}{c}-0.02 \\
(-2.60)\end{array}$ & $\begin{array}{c}-0.01 \\
(-1.90)\end{array}$ \\
\hline Landlock dummy & & & & $\begin{array}{c}0.24 \\
(0.46)\end{array}$ & \\
\hline Ethnic fractionalization & & & & $\begin{array}{c}-0.00 \\
(-0.45)\end{array}$ & \\
\hline $\begin{array}{l}\text { Growth in trading partners' } \\
\text { GDP per capita }\end{array}$ & & & & $\begin{array}{c}0.42 \\
(1.07)\end{array}$ & \\
\hline World GDP per capita growth & & & & $\begin{array}{c}-0.01 \\
(-0.02)\end{array}$ & \\
\hline Adjusted R-squared & 0.04 & 0.33 & 0.36 & 0.45 & 0.31 \\
\hline
\end{tabular}

Notes Dependent variable: real GDP per capita growth (1985 constant US\$).

Heteroskedasticity-consistent t-statistics in parentheses. 
Table 7. Impact of Growth in South Africa on Growth in Rest of Sub-Saharan Africa: Pooled Panel, 1980-99

\begin{tabular}{|c|c|c|c|c|c|}
\hline Independent Variables & (1) & (2) & (3) & (4) & (5) \\
\hline Constant & $\begin{array}{c}0.31 \\
(1.01)\end{array}$ & $\begin{array}{l}-4.91 \\
(-1.69)\end{array}$ & $\begin{array}{l}-5.87 \\
(-0.79)\end{array}$ & $\begin{array}{l}5.95 \\
(0.78)\end{array}$ & $\begin{array}{c}0.48 \\
(0.46)\end{array}$ \\
\hline $\begin{array}{l}\text { Per capita GDP growth in } \\
\text { South Africa }\end{array}$ & $\begin{array}{c}0.59 \\
(2.38)\end{array}$ & $\begin{array}{c}0.44 \\
(2.15)\end{array}$ & $\begin{array}{c}0.64 \\
(3.02)\end{array}$ & $\begin{array}{c}0.90 \\
(3.12)\end{array}$ & $\begin{array}{c}0.58 \\
(2.97)\end{array}$ \\
\hline ln (initial GDP per capita) & & $\begin{array}{c}0.24 \\
(0.50)\end{array}$ & $\begin{array}{c}0.52 \\
(0.55)\end{array}$ & $\begin{array}{l}-0.56 \\
(-0.60)\end{array}$ & \\
\hline Investment/GDP & & $\begin{array}{c}0.19 \\
(3.68)\end{array}$ & $\begin{array}{c}0.17 \\
(3.76)\end{array}$ & $\begin{array}{c}0.27 \\
(3.34)\end{array}$ & $\begin{array}{c}0.11 \\
(3.36)\end{array}$ \\
\hline Age dependency ratio & & & $\begin{array}{c}0.74 \\
(0.21)\end{array}$ & $\begin{array}{l}-4.81 \\
(-1.33)\end{array}$ & \\
\hline Trade/GDP & & & $\begin{array}{l}-0.01 \\
(-0.85)\end{array}$ & $\begin{array}{l}-0.03 \\
(-1.75)\end{array}$ & \\
\hline Primary school enrollment & & & $\begin{array}{l}-0.00 \\
(-0.30)\end{array}$ & $\begin{array}{c}0.00 \\
(0.07)\end{array}$ & \\
\hline Secondary school enrollment & & & $\begin{array}{c}0.01 \\
(0.24)\end{array}$ & $\begin{array}{c}0.01 \\
(0.12)\end{array}$ & \\
\hline Inflation rate & & & $\begin{array}{l}-0.001 \\
(-7.47)\end{array}$ & $\begin{array}{l}-0.001 \\
(-7.53)\end{array}$ & $\begin{array}{l}-0.001 \\
(-8.71)\end{array}$ \\
\hline Aid/GDP & & & & $\begin{array}{c}0.07 \\
(1.69)\end{array}$ & $\begin{array}{c}0.05 \\
(2.62)\end{array}$ \\
\hline Infant mortality rate & & & & $\begin{array}{l}-0.02 \\
(-1.97)\end{array}$ & $\begin{array}{c}-0.03 \\
(-3.18)\end{array}$ \\
\hline Landlock dummy & & & & $\begin{array}{c}0.60 \\
(1.10)\end{array}$ & \\
\hline Ethnic fractionalization & & & & $\begin{array}{c}0.00 \\
(0.41)\end{array}$ & \\
\hline $\begin{array}{l}\text { Growth in trading partners' } \\
\text { GDP per capita }\end{array}$ & & & & $\begin{array}{c}0.35 \\
(0.77)\end{array}$ & \\
\hline World GDP per capita growth & & & & $\begin{array}{c}0.13 \\
(0.18)\end{array}$ & \\
\hline Adjusted R-squared & 0.03 & 0.30 & 0.30 & 0.35 & 0.30 \\
\hline
\end{tabular}

Notes: Dependent variable: real GDP per capita growth (1985 constant US\$). Heteroskedasticity-consistent t-statistics in parentheses. 
Table 8. Impact of Growth in South Africa on Growth in Rest of Sub-Saharan Africa: Panel with Fixed Effects, 1960-99

\begin{tabular}{|c|c|c|c|c|c|}
\hline Independent Variables & (1) & (2) & (3) & (4) & (5) \\
\hline $\begin{array}{l}\text { Per capita GDP growth in } \\
\text { South Africa }\end{array}$ & $\begin{array}{c}0.47 \\
(5.04)\end{array}$ & $\begin{array}{c}0.69 \\
(6.24)\end{array}$ & $\begin{array}{c}0.55 \\
(4.04)\end{array}$ & $\begin{array}{c}0.46 \\
(2.17)\end{array}$ & $\begin{array}{c}0.50 \\
(3.27)\end{array}$ \\
\hline ln (initial GDP per capita) & & $\begin{array}{l}-2.60 \\
(-2.00)\end{array}$ & $\begin{array}{l}-7.14 \\
(-4.45)\end{array}$ & $\begin{array}{l}-5.86 \\
(-3.22)\end{array}$ & \\
\hline Investment/GDP & & $\begin{array}{c}0.22 \\
(5.30)\end{array}$ & $\begin{array}{c}0.24 \\
(3.69)\end{array}$ & $\begin{array}{c}0.38 \\
(5.32)\end{array}$ & $\begin{array}{c}0.27 \\
(5.00)\end{array}$ \\
\hline Age dependency ratio & & & $\begin{array}{l}-4.40 \\
(-0.99)\end{array}$ & $\begin{array}{l}-2.24 \\
(-0.45)\end{array}$ & \\
\hline Trade/GDP & & & $\begin{array}{c}0.00 \\
(0.23)\end{array}$ & $\begin{array}{c}0.01 \\
(0.23)\end{array}$ & \\
\hline Primary school enrollment & & & $\begin{array}{c}0.03 \\
(1.04)\end{array}$ & $\begin{array}{c}0.00 \\
(0.08)\end{array}$ & \\
\hline Secondary school enrollment & & & $\begin{array}{l}-0.06 \\
(-1.57)\end{array}$ & $\begin{array}{l}-0.02 \\
(-043)\end{array}$ & \\
\hline Inflation rate & & & $\begin{array}{l}-0.001 \\
(-8.69)\end{array}$ & $\begin{array}{l}-0.001 \\
(-7.76)\end{array}$ & $\begin{array}{l}-0.001 \\
(-5.09)\end{array}$ \\
\hline Aid/GDP & & & & $\begin{array}{l}-0.03 \\
(-0.72)\end{array}$ & \\
\hline Infant mortality rate & & & & $\begin{array}{c}0.00 \\
(0.00)\end{array}$ & $\begin{array}{c}-0.01 \\
(-1.90)\end{array}$ \\
\hline $\begin{array}{l}\text { Growth in trading partners' } \\
\text { GDP per capita }\end{array}$ & & & & $\begin{array}{c}0.42 \\
(0.95)\end{array}$ & $\begin{array}{c}0.63 \\
(2.61)\end{array}$ \\
\hline World GDP per capita growth & & & & $\begin{array}{c}-0.09 \\
(-0.13)\end{array}$ & \\
\hline Adjusted R-squared & 0.21 & 0.39 & 0.48 & 0.51 & 0.34 \\
\hline
\end{tabular}

Notes: Dependent variable: real GDP per capita growth (1985 constant US\$).

Heteroskedasticity-consistent t-statistics in parentheses. 
Table 9. Impact of Growth in South Africa on Growth in Rest of Sub-Saharan Africa: Panel with Fixed Effects, 1980-99

\begin{tabular}{|c|c|c|c|c|c|}
\hline Independent Variables & (1) & (2) & (3) & (4) & (5) \\
\hline $\begin{array}{l}\text { Per capita GDP growth in } \\
\text { South Africa }\end{array}$ & $\begin{array}{c}0.61 \\
(3.19)\end{array}$ & $\begin{array}{c}0.40 \\
(2.53)\end{array}$ & $\begin{array}{c}0.64 \\
(4.30)\end{array}$ & $\begin{array}{c}0.48 \\
(1.97)\end{array}$ & $\begin{array}{c}0.33 \\
(1.82)\end{array}$ \\
\hline ln (initial GDP per capita) & & $\begin{array}{l}-2.29 \\
(-1.17)\end{array}$ & $\begin{array}{l}-10.20 \\
(-4.34)\end{array}$ & $\begin{array}{l}-10.73 \\
(-3.77)\end{array}$ & \\
\hline Investment/GDP & & $\begin{array}{c}0.28 \\
(5.01)\end{array}$ & $\begin{array}{c}0.33 \\
(4.44)\end{array}$ & $\begin{array}{c}0.39 \\
(3.73)\end{array}$ & $\begin{array}{c}0.20 \\
(2.83)\end{array}$ \\
\hline Age dependency ratio & & & $\begin{array}{l}-9.83 \\
(-1.91)\end{array}$ & $\begin{array}{l}-14.76 \\
(-2.78)\end{array}$ & \\
\hline Trade/GDP & & & $\begin{array}{c}0.01 \\
(0.45)\end{array}$ & $\begin{array}{c}0.02 \\
(0.60)\end{array}$ & \\
\hline Primary school enrollment & & & $\begin{array}{c}0.08 \\
(2.58)\end{array}$ & $\begin{array}{c}0.10 \\
(3.03)\end{array}$ & \\
\hline Secondary school enrollment & & & $\begin{array}{l}-0.11 \\
(-2.89)\end{array}$ & $\begin{array}{l}-0.15 \\
(-2.03)\end{array}$ & \\
\hline Inflation rate & & & $\begin{array}{l}-0.001 \\
(-9.08)\end{array}$ & $\begin{array}{l}-0.001 \\
(-8.39)\end{array}$ & $\begin{array}{l}-0.001 \\
(-3.07)\end{array}$ \\
\hline Aid/GDP & & & & $\begin{array}{l}-0.01 \\
(-0.44)\end{array}$ & \\
\hline Infant mortality rate & & & & $\begin{array}{c}0.01 \\
(0.43)\end{array}$ & \\
\hline $\begin{array}{l}\text { Growth in trading partners' } \\
\text { GDP per capita }\end{array}$ & & & & $\begin{array}{l}-0.29 \\
(-0.72)\end{array}$ & \\
\hline World GDP per capita growth & & & & $\begin{array}{c}1.02 \\
(1.79)\end{array}$ & $\begin{array}{c}0.75 \\
(2.09)\end{array}$ \\
\hline Adjusted R-squared & 0.15 & 0.36 & 0.52 & 0.50 & 0.26 \\
\hline
\end{tabular}

Notes: Dependent variable: real GDP per capita growth (1985 constant US\$).

Heteroskedasticity-consistent t-statistics in parentheses. 
Table 10. Impact of Growth in South Africa on Growth in Rest of Sub-Saharan Africa: Importance of Trade Shares with and Distance from South Africa, 1960-99

\begin{tabular}{|c|c|c|c|c|c|c|c|c|}
\hline Independent Variables & $\begin{array}{c}\text { Pooled } \\
\text { Panel }\end{array}$ & $\begin{array}{c}\text { Pooled } \\
\text { Panel }\end{array}$ & $\begin{array}{l}\text { Fixed } \\
\text { Effects }\end{array}$ & $\begin{array}{l}\text { Fixed } \\
\text { Effects }\end{array}$ & $\begin{array}{c}\text { Pooled } \\
\text { Panel }\end{array}$ & $\begin{array}{c}\text { Pooled } \\
\text { Panel }\end{array}$ & $\begin{array}{l}\text { Fixed } \\
\text { Effects }\end{array}$ & $\begin{array}{l}\text { Fixed } \\
\text { Effects }\end{array}$ \\
\hline Constant & $\begin{array}{c}5.49 \\
(0.91)\end{array}$ & $\begin{array}{l}3.86 \\
(0.61)\end{array}$ & & & $\begin{array}{l}-8.98 \\
(-1.54)\end{array}$ & $\begin{array}{l}-6.78 \\
(-1.10)\end{array}$ & & \\
\hline $\begin{array}{l}\text { Per capita GDP growth in } \\
\text { South Africa }\end{array}$ & $\begin{array}{c}0.79 \\
(5.04)\end{array}$ & & $\begin{array}{c}0.62 \\
(4.34)\end{array}$ & & $\begin{array}{l}1.03 \\
(2.60)\end{array}$ & & $\begin{array}{c}0.53 \\
(1.78)\end{array}$ & \\
\hline $\begin{array}{l}\text { Trade-with-South-Africa } \\
\text { weighted per capita GDP } \\
\text { growth in South Africa }\end{array}$ & $\begin{array}{l}-1.06 \\
(-0.83)\end{array}$ & $\begin{array}{c}3.02 \\
(2.18)\end{array}$ & $\begin{array}{c}0.21 \\
(0.20)\end{array}$ & $\begin{array}{l}2.63 \\
(2.58)\end{array}$ & & & & \\
\hline $\begin{array}{l}\text { Distance-from-South-Africa } \\
\text { weighted per capita GDP } \\
\text { growth in South Africa }\end{array}$ & & & & & $\begin{array}{l}-19.04 \\
(-1.09)\end{array}$ & $\begin{array}{l}24.80 \\
(3.52)\end{array}$ & $\begin{array}{l}-4.88 \\
(-0.40)\end{array}$ & $\begin{array}{l}16.61 \\
(2.98)\end{array}$ \\
\hline ln (initial GDP per capita) & $\begin{array}{c}-0.63 \\
(-0.88)\end{array}$ & $\begin{array}{l}-0.11 \\
(-0.15)\end{array}$ & $\begin{array}{l}-6.58 \\
(-4.03)\end{array}$ & $\begin{array}{l}-7.20 \\
(-4.27)\end{array}$ & $\begin{array}{c}1.06 \\
(1.56)\end{array}$ & $\begin{array}{c}0.89 \\
(1.25)\end{array}$ & $\begin{array}{l}-5.74 \\
(-3.44)\end{array}$ & $\begin{array}{c}-5.91 \\
(-3.52)\end{array}$ \\
\hline Investment/GDP & $\begin{array}{c}0.29 \\
(5.85)\end{array}$ & $\begin{array}{c}0.27 \\
(4.76)\end{array}$ & $\begin{array}{c}0.39 \\
(5.79)\end{array}$ & $\begin{array}{c}0.39 \\
(5.07)\end{array}$ & $\begin{array}{c}0.17 \\
(4.46)\end{array}$ & $\begin{array}{c}0.17 \\
(4.00)\end{array}$ & $\begin{array}{c}0.17 \\
(2.82)\end{array}$ & $\begin{array}{c}0.16 \\
(2.59)\end{array}$ \\
\hline Age dependency ratio & $\begin{array}{c}-4.17 \\
(-1.38)\end{array}$ & $\begin{array}{l}-5.23 \\
(-1.68)\end{array}$ & $\begin{array}{l}-5.77 \\
(-1.29)\end{array}$ & $\begin{array}{l}-10.34 \\
(-2.48)\end{array}$ & $\begin{array}{c}0.76 \\
(0.27)\end{array}$ & $\begin{array}{l}-0.31 \\
(-0.11)\end{array}$ & $\begin{array}{c}-4.45 \\
(-0.93)\end{array}$ & $\begin{array}{l}-4.76 \\
(-0.99)\end{array}$ \\
\hline Trade/GDP & $\begin{array}{c}-0.02 \\
(-1.38)\end{array}$ & $\begin{array}{c}-0.02 \\
(-1.42)\end{array}$ & $\begin{array}{l}-0.002 \\
(-0.06)\end{array}$ & $\begin{array}{l}-0.005 \\
(-0.19)\end{array}$ & $\begin{array}{l}-0.005 \\
(-0.40)\end{array}$ & $\begin{array}{l}-0.003 \\
(-0.29)\end{array}$ & $\begin{array}{c}0.02 \\
(0.75)\end{array}$ & $\begin{array}{c}0.02 \\
(0.75)\end{array}$ \\
\hline Primary school enrollment & $\begin{array}{c}-0.01 \\
(-0.84)\end{array}$ & $\begin{array}{c}-0.01 \\
(-0.57)\end{array}$ & $\begin{array}{c}0.01 \\
(0.28)\end{array}$ & $\begin{array}{c}0.01 \\
(0.27)\end{array}$ & $\begin{array}{c}-0.01 \\
(-0.62)\end{array}$ & $\begin{array}{c}-0.01 \\
(-0.44)\end{array}$ & $\begin{array}{c}0.02 \\
(0.84)\end{array}$ & $\begin{array}{c}0.02 \\
(0.74)\end{array}$ \\
\hline $\begin{array}{l}\text { Secondary school } \\
\text { enrollment }\end{array}$ & $\begin{array}{c}0.02 \\
(0.56)\end{array}$ & $\begin{array}{c}-0.01 \\
(-0.40)\end{array}$ & $\begin{array}{c}-0.01 \\
(-0.22)\end{array}$ & $\begin{array}{c}-0.07 \\
(-1.45)\end{array}$ & $\begin{array}{l}-0.01 \\
(-0.52)\end{array}$ & $\begin{array}{c}-0.02 \\
(-0.83)\end{array}$ & $\begin{array}{l}-0.10 \\
(-2.73)\end{array}$ & $\begin{array}{l}-0.10 \\
(-2.73)\end{array}$ \\
\hline Inflation rate & $\begin{array}{l}-0.001 \\
(-9.09)\end{array}$ & $\begin{array}{l}-0.001 \\
(-8.02)\end{array}$ & $\begin{array}{l}-0.001 \\
(-7.99)\end{array}$ & $\begin{array}{l}-0.001 \\
(-8.89)\end{array}$ & $\begin{array}{l}-0.001 \\
(-8.24)\end{array}$ & $\begin{array}{l}-0.001 \\
(-7.86)\end{array}$ & $\begin{array}{l}-0.001 \\
(-7.74)\end{array}$ & $\begin{array}{l}-0.001 \\
(-9.48)\end{array}$ \\
\hline Adjusted R-squared & 0.43 & 0.33 & 0.54 & 0.48 & 0.37 & 0.34 & 0.53 & 0.53 \\
\hline
\end{tabular}

Notes: Dependent variable: real GDP per capita growth (1985 constant US\$). Heteroskedasticity-consistent t-statistics in parentheses. 
Table 11. Growth Spillovers in Sub-Sahara Africa: Impact of Each Country Other Than South Africa; Panel with Fixed Effects, 1960-99

\begin{tabular}{|c|c|c|}
\hline Country & Estimate of Growth Impact & t-statistic \\
\hline Benin & 0.31 & 1.50 \\
\hline Botswana** & 0.15 & 2.53 \\
\hline Burkina Faso & 0.02 & 0.07 \\
\hline Burundi & -0.07 & -0.73 \\
\hline Cameroon** & 0.12 & 2.18 \\
\hline Central African Republic* & 0.37 & 1.83 \\
\hline Chad & -0.02 & -0.20 \\
\hline Congo, Dem. Rep. of & 0.10 & 1.43 \\
\hline Congo, Rep. & 0.01 & 0.09 \\
\hline Cote d'Ivoire & 0.09 & 0.85 \\
\hline Gabon & 0.03 & 0.37 \\
\hline Gambia, The & -0.09 & -0.43 \\
\hline Ghana & -0.07 & -0.53 \\
\hline Guinea-Bissau & -0.21 & -0.70 \\
\hline Kenya* & 0.62 & 1.96 \\
\hline Lesotho & -0.04 & -0.37 \\
\hline Liberia & -0.09 & -0.41 \\
\hline Madagascar & -0.17 & -0.47 \\
\hline Malawi & -0.03 & -0.20 \\
\hline Mali & -0.06 & -0.46 \\
\hline Mauritania & -0.20 & -1.95 \\
\hline Mauritius & 0.03 & 0.48 \\
\hline Niger & -0.05 & -0.58 \\
\hline Nigeria & 0.03 & 0.52 \\
\hline Rwanda** & 0.21 & 2.40 \\
\hline Senegal & 0.18 & 1.22 \\
\hline Seychelles & -0.09 & -1.15 \\
\hline Sierra Leone & 0.02 & 0.11 \\
\hline Somalia & 0.14 & 1.34 \\
\hline Sudan & 0.01 & 0.13 \\
\hline Swaziland & -0.13 & -0.97 \\
\hline Togo* & 0.16 & 1.85 \\
\hline Zambia & -0.39 & -1.51 \\
\hline Zimbabwe** & 0.19 & 2.54 \\
\hline
\end{tabular}

Notes: The dependent variable is real per capita GDP, excluding the country with its growth rate on the right hand side of the equation each time. The specification of the model is given by regression (4) in Table 8 (with fixed effects, for the period 1960-99). The impact of each country on growth in the rest of Sub-Sahara Africa is estimated only for countries with at least six observations for growth. The t-statistics are heteroskedasticityconsistent. 
Table 12. Impact of Growth in South Africa on Growth in Rest of Sub-Saharan Africa: Role of Regional Trends, 1960-99

\begin{tabular}{lcc}
\hline Independent Variables & Pooled panel & Fixed effects \\
\hline Constant & -3.53 & \\
& $(-0.63)$ & \\
Per capita GDP growth in South Africa & 0.56 & 0.45 \\
& $(3.19)$ & $(2.67)$ \\
Per capita GDP growth in the rest of Africa & 0.26 & 0.22 \\
& $(1.59)$ & $(1.61)$ \\
In (initial GDP per capita) & 0.37 & -7.02 \\
& $(0.54)$ & $(-4.54)$ \\
Investment/GDP & 0.20 & 0.24 \\
& $(4.61)$ & $(3.65)$ \\
Age dependency ratio & -0.59 & -4.14 \\
& $(-0.20)$ & $(-0.94)$ \\
Trade/GDP & -0.01 & 0.01 \\
Primary school enrollment & $(-0.73)$ & $(0.28)$ \\
Secondary school enrollment & -0.01 & 0.03 \\
Inflation rate & $(-0.76)$ & $(1.01)$ \\
& & -0.05 \\
& 0.01 & $(-1.29)$ \\
& $(0.16)$ & -0.001 \\
& -0.001 & $(-8.91)$ \\
& $(-8.54)$ & 0.51 \\
\hline
\end{tabular}

Notes: Dependent variable: real GDP per capita growth (1985 constant US\$).

Heteroskedasticity-consistent t-statistics in parentheses. 


\section{References}

Arora, V., and A. Vamvakidis, 2004a, "The Impact of U.S. Economic Growth on the Rest of the World: How Much Does It Matter?” Journal of Economic Integration, Vol. 19 (March), pp. 1-18.

- 2004b, "How Much Do Trading Partners Matter for Economic Growth?” IMF Working Paper 04/26 (Washington: International Monetary Fund), forthcoming in IMF Staff Papers.

Barro, R., and Xavier Sala-ì-Martin, 1995, Economic Growth (New York: McGraw Hill).

Bloom, David E. and Jeffrey D. Sachs, 1998, "Geography, Demography, and Economic Growth in Africa," Brookings Papers on Economic Activity, Issue. 2, Brookings Institution, pp. 207-73.

Caselli, Francesco, Gerardo Esquivel, and Fernando Lefort, 1996, "Reopening the Convergence Debate: A New Look at Cross-Country Growth Empirics," Journal of Economic Growth, Vol. 1 (September), pp. 363-89.

Grossman, Gene and Elhanan Helpman, 1991, Innovation and Growth in the Global Economy Cambridge, Masachusetts: MIT Press.

Levine, Ross, and David Renelt, 1992, “A Sensitivity Analysis of Cross-Country Growth Regressions," American Economic Review, Vol. 82 (September), pp. 942-63.

Moulton, R. Brent, 1990, “An Illustration of a Pitfall in Estimating the Effects of Aggregate Variables on Micro Units," Review of Economics and Statistics, Vol. 72, No. 2 (May), pp. 334-38.

Rivera-Batiz, Luis and Paul Romer, 1991, "Economic Integration and Endogenous Growth," Quarterly Journal of Economics, Vol. 106, No. 2 (May), pp. 531-55.

Romer, Paul M., 1990, “Endogenous Technological Change,” Journal of Political Economy, Vol. 98, No. 5, Part 2 (October), pp. 71-102.

Sachs, Jeffrey D., and Andrew Warner, 1995, "Economic Reform and the Process of Global Integration," Brookings Papers on Economic Activity: 1, Brookings Institution, pp. 1-95. 